\title{
Incorporation of pectin during biosynthesis of bacterial cellulose by Gluconacetobacter xylinus InaCC B404: Possibility for producing green food packaging
}

\author{
SUKMIYATI AGUSTIN ${ }^{1,3}$, ENDANG TRI WAHYUNI ${ }^{2}$, SUPARMO ${ }^{1}$, SUPRIYADI $^{1}$, \\ MUHAMMAD NUR CAHYANTO ${ }^{1, \bullet}$ \\ ${ }^{1}$ Department of Food and Agricultural Product Technology, Faculty of Agricultural Technology, Universitas Gadjah Mada. Jl. Flora, Bulaksumur, \\ Sleman 55281, Yogyakarta, Indonesia. Tel./fax.: +62-274-549650, `email: mn_cahyanto@ugm.ac.id \\ ${ }^{2}$ Department of Chemistry, Faculty of Mathematics and Natural Sciences, Universitas Gadjah Mada. J1. Sekip Utara, Bulaksumur, Sleman 55281, \\ Yogyakarta, Indonesia \\ ${ }^{3}$ Department of Agricultural Product Technology, Faculty of Agriculture, Universitas Mulawarman. Jl. Pasir Balengkong, Gunung Kelua, Samarinda \\ 75123, East Kalimantan, Indonesia
}

Manuscript received: 4 March 2020. Revision accepted: 13 April 2021.

\begin{abstract}
Agustin S, Wahyuni ET, Suparmo, Supriyadi, Cahyanto MN. 2021. Incorporation of pectin during biosynthesis of bacterial cellulose by Gluconacetobacter xylinus InaCC B404: Possibility for producing green food packaging. Biodiversitas 22: $2548-2553$. Bacterial cellulose-pectin biocomposite is developed as a potential environmentally friendly food packaging material. The objective of this research was to investigate the effects of pectin supplementation to the growth medium of Gluconacetobacter xylinus on the properties of the biocomposite produced. Pectin was added into the growth medium at different concentrations, i.e.: $0.1,0.2$ and $0.3 \%$ (w/v). The bacterial cellulose-pectin biocomposites produced were analyzed for structure, mechanical strength, crystallinity, morphology, color and opacity. FTIR analysis suggested that interaction between bacterial cellulose and pectin was hydrogen bonding. Generally, pectin addition decreased the crystallinity, tensile strength, tear strength and lightness of biocomposite produced. The tensile and tear strength of bacterial cellulose-pectin biocomposites were in the range of $23.05-25.72 \mathrm{MPa}$ and $13.30-15.72 \mathrm{~g} / \mu \mathrm{m}$ respectively, comparable to those conventional non-biodegradable plastics such as high-density polyethylene and low-density polyethylene with opacity much lower than HDPE. These results suggesting the possibility of cellulose-pectin biocomposite as semi-translucent green food packaging.
\end{abstract}

Keywords: Bacterial cellulose, Gluconacetobacter xylinus, pectin

\section{INTRODUCTION}

Cellulose is the foremost inexhaustible renewable polymer in nature, comprising glucose units connected by $\beta-(1,4)$ bonds, created by different life forms such as plants, bacteria, algae, and animals. Bacterial cellulose (BC) is an exopolysaccharide formed primarily by the bacteria Gluconacetobacter xylinus. Bacterial cellulose possesses a chemical structure similar to that of plant cellulose, with several advantages including reticulate structure stabilized by inter-and intra-hydrogen bonds, high purity, high degree of polymerization (up to 8000) and high mechanical strength (Barud et al. 2011). Despite these advantages, the high degree of crystallinity possessed by bacterial cellulose makes this material has the disadvantage of being very stiff, thus limiting its application as packaging material. Bacterial cellulose, on the other hand, has abundant hydroxyl groups on the surface, so that modification of the cellulose structure is possible ( $\mathrm{Hu}$ et al. 2014).

By controlling the conditions of cultivation, the shape and structure of bacterial cellulose can be regulated. Several studies have shown that adding additives to bacterial growth media can modify the composition, morphology and characteristics of the bacterial cellulose produced. These compounds can infiltrate the cellulose structure in the biosynthesis process, or can also influence the formation of fibrils or ribbons, thereby changing the structure of the resulting cellulose, including changing the size of the fibrils, degree of crystallinity and crystal size (Klemm et al. 2006; Ruka et al. 2013). Bacterial cellulose is composed of nanometer-sized subfibrils that are crystallized into microfibrils (Yamanaka et al. 2000). Additives in the cellulose-producing bacteria growth media will interfere with the crystallization of glucan chains (Tokoh et al. 2002), thus affected the characteristics of cellulose produced.

Some studies have been done to evaluate the effect of additives incorporated in the growth medium of celluloseproducing bacteria. The fuse of water-dissolved polymers such as carboxymethylcellulose (CMC), hydroxypropylmethyl cellulose (HPMC) and methylcellulose (MC) into the growth medium causes a decrease in crystallinity and crystallite size, as well as increases heat steadiness, pore size, capability of water retention and capacity for ion absorption (Chen et al. 2011). The addition of Na-alginate to the medium resulted in macromorphological changes in cellulose, reducing crystallinity and crystallite size (Zhou et al. 2007; Sya'di et al. 2016). Some additives that have been tested for their impact on the yield, morphology and crystalline structure of bacterial cellulose are chitosan, 
starch, agar, gelatin, pectin, poly-3-hydroxybutyrate, aloe vera and xyloglucan (Saibuatong and Phisalaphong 2010; Ruka et al 2013; Chen et al. 2014; Jia et al. 2017; Szymanska-Chargot et al. 2017; Sya'di et al. 2017a).

Pectin, a complex polymer of heterosaccharide found in almost all higher plants in the middle lamella or the primary cell wall, is an ester of methylated D-galacturonic acid. In plant cells, pectin forms independent network even though it is close to cellulose (Tokoh et al. 2002). Several studies have used pectin as an additive in growth media for cellulose-producing bacteria to understand the interactions of the two polysaccharides in plant cell walls (Lin et al. 2018; Lin et al. 2016; Szymanska-Chargot et al. 2017). However, research on bacterial cellulose-pectin (BCP) biocomposite as an environmentally friendly food packaging material has not been widely explored. Increased concern about environmental pollution and environmental imbalances as a result of the widespread use of nonbiodegradable plastic packaging materials has stimulated research into alternative food packaging materials based on biopolymers, including bacterial cellulose and pectin. This research aimed to investigate the physicochemical properties of bacterial cellulose modified in situ with the addition of pectin to the growth medium of G. xylinus InaCC B404 and associate it with the possibility of making the biocomposite as green packaging material.

\section{MATERIALS AND METHODS}

\section{Materials}

The microorganism used in the production of biocomposites was Gluconacetobacter xylinus InaCC B404 obtained from the culture collection of the LIPI Biotechnology Center Bogor, Indonesia. The strain was cultured in Hestrin-Schramm (HS) media containing $2 \%$ Dglucose, $0.5 \%$ peptone, $0.5 \%$ yeast extract, $0.27 \%$ $\mathrm{Na}_{2} \mathrm{HPO}_{4}$ and $0.115 \%$ citric acid monohydrate.

\section{Methods}

\section{Preparation of bacterial cellulose composite}

Bacterial cellulose was produced by G. xylinus InaCC B404 using Hestrin Schramm media as described by Sya'di et al. (2017b). Various concentrations of pectin $(0.1,0.2$ and $0.3 \% \mathrm{w} / \mathrm{v}$ ) were incorporated into the media. Cultures were grown at $30^{\circ} \mathrm{C}$ for 7 days under static conditions. After the incubation period was completed, the pellicle formed was harvested and boiled in $0.1 \mathrm{~N}$ sodium hydroxide for 30 minutes accompanied by rinsing with pure $\mathrm{H}_{2} \mathrm{O}$ until neutral $\mathrm{pH}$ was achieved. For the purposes of measuring morphological, physical, and mechanical properties of the composite, the harvested pellicles were then dried by freeze-drying method for 15-24 hours.

\section{Physicochemical analysis \\ BC morphology}

Scanning electron microscope instrument of SEM JEOL JSM-6510 LA type has been used to conform the morphology of the BC and BCP composites according to Ul-Islam et al. (2011). Sputter was coated with gold in freeze-dried samples. Acceleration voltage at $15 \mathrm{kV}$ was used for sample examination.

\section{$B C$ crystallinity}

Using a Rigaku Miniflex600, freeze-dried samples of BCP composites were X-rayed. X-ray diffraction patterns $(40 \mathrm{kV}, 15 \mathrm{~mA})$ were reported at the $\mathrm{CuK} \alpha$ radiation wavelength $\left(\lambda=1.54^{\circ} \mathrm{A}\right)$ based on the methodology of Huang et al. (2010). Samples were scanned at scan speed of $0.02^{\circ} \mathrm{min}^{-1}$ from $10-30^{\circ} 2 \theta$-range. The crystallinity $(\mathrm{Cr})$ and crystallite size $(\mathrm{CrS})$ were determined depended on $\mathrm{X}$ beam diffraction estimations. Crystallinity was determined using equation as follows:

$$
\operatorname{Cr}(\%)=\frac{S c}{S t} \times 100 \%
$$

Where: Sc is sum of crystalline area and St is sum of total area. Scherrer equation was used to obtained $\mathrm{CrS}$ as follows:

$$
\operatorname{Cr} S=\frac{K \lambda}{\beta \cos \theta}
$$

Where: $K$ is the shape factor $(0.9), \lambda$ is the $x$-ray wavelength $\left(1.54^{\circ} \mathrm{A}\right), \beta$ is the full width at half maximum height (FWHM), and $\theta$ is the Bragg's angle $\left({ }^{\circ}\right)$.

\section{Functional group}

With a Shimadzu-8201 PC Corp. (Japan) spectrophotometer, FT-IR spectra were obtained with a resolution of $4 \mathrm{~cm}^{-1}$, working in the range of $400-4000 \mathrm{~cm}^{-}$ ${ }^{1}$. All samples were mixed with $\mathrm{KBr}$ to produce $\mathrm{KBr}$-pellet prior to spectra measurement (Ul-Islam et al. 2011).

\section{Color and opacity}

A colorimeter (CR-400 Konica Minolta, Japan) along with a CIELab color space was measured for film color. Values of L* (lightness: $0=$ black, $100=$ white $), a^{*}\left(-a^{*}\right.$ to greenness, $+a^{*}$ to redness) and $b^{*}\left(-b^{*}\right.$ to blueness, $+b^{*}$ to yellowness) were determined according to Wang et al. (2018). The total color difference $(\Delta \mathrm{E})$ was obtained using the following equation:

$$
\Delta E=\sqrt{(\Delta L *)^{2}+(\Delta a *)^{2}+(\Delta b *)^{2}}
$$

Where: $\Delta \mathrm{L}^{*}, \Delta \mathrm{a}^{*}$, and $\Delta \mathrm{b}^{*}$ are the differences between the color values of the pure $\mathrm{BC}$ film and the $\mathrm{BCP}$ films.

The opacity was reported according to the methodology of Wang et al (2018). The films were shaped into rectangular and positioned using air as a reference in the spectrophotometer test cell. Film opacity at $600 \mathrm{~nm}$ was reported as follows:

$$
\text { Opacity }=A_{600} / x
$$

Where: $A_{600}$ is the absorbance at $600 \mathrm{~nm}$ and $\mathrm{X}$ is the film thickness $(\mathrm{mm})$. 


\section{Mechanical properties}

The tensile and tear strength of the film were measured using Universal Testing Machine (UTM) ZWICK Z.05type mechanical tester based on ASTM-D882-02 (2002). The sample films were cut into strips of $2 \mathrm{~cm}$ width and 10 $\mathrm{cm}$ long prior to measurement. The thickness of all films was determined using a thickness gauge (Mitutoyo 7321) and then inserted into the locking grip. The films were extended with $50 \mathrm{~mm}$ of beginning hold detachment and 10 $\mathrm{mm} / \mathrm{min}$ test speed.

\section{Data analysis}

In order to assess any important variations between the treatments, the data collected was further analyzed using Analysis of Variance (ANOVA) followed by Duncan's multiple range test at $95 \%$ confidence level $(\mathrm{p} \leq 0.05)$ by SPSS Statistic Software Version 25 (2017). All data were presented in the form of mean \pm SD.

\section{RESULTS AND DISCUSSION}

\section{Functional groups}

Because of the strong bonding with hydrogen between cellulose molecules, the FTIR spectrum of BC (Fig 1.) showed a peak area of $3426 \mathrm{~cm}^{-1}$ suggesting stretching vibration of OH groups. The peaks in the areas of $2916 \mathrm{~cm}$ ${ }^{1}$ and $1427 \mathrm{~cm}^{-1}$ are the stretching vibration region of the C$\mathrm{H}$ groups due to symmetrical $\mathrm{CH}$ deformation (Ul-Islam et al. 2011). The area of deformational vibrations of $\mathrm{OH}$ groups of bound water is the peak indicated at $1642 \mathrm{~cm}^{-1}$. The peaks in the $1500-1200 \mathrm{~cm}^{-1}$ range are sensitive to changes in chemical and molecular structures, while the peaks in the $1200-1000 \mathrm{~cm}^{-1}$ range correspond to the vibrations of the $\mathrm{C}-\mathrm{O}-\mathrm{C}$ and $\mathrm{C}-\mathrm{O}$ ranges, and the peaks in the $895 \mathrm{~cm}^{-1}$ range indicate vibrations of the $\beta-1,4$ bonds (Atykyan et al. 2020).

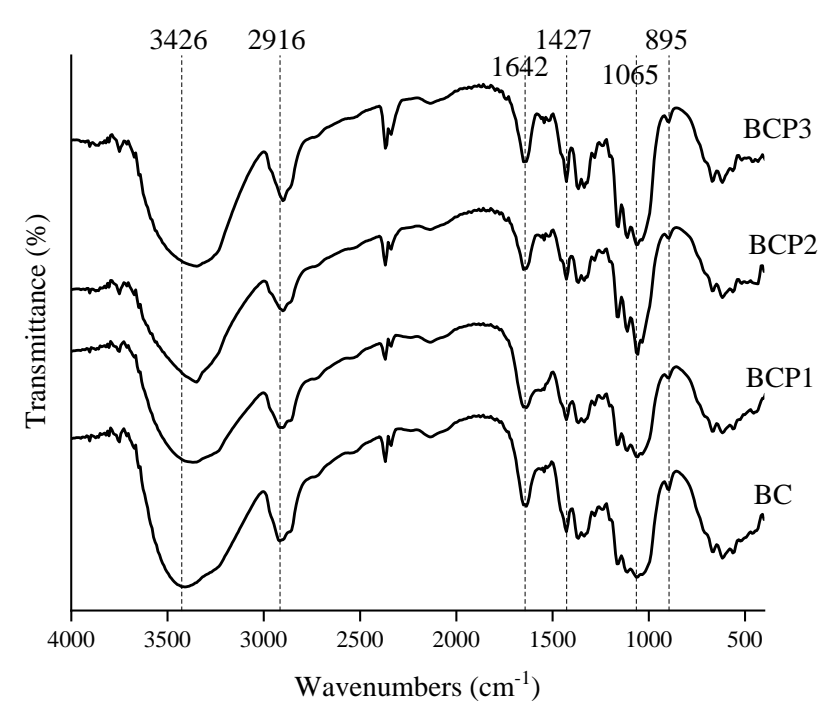

Figure 1. FTIR spectrum of BC incorporated with various pectin concentration
Compared to BC native, FTIR spectra of BCP revealed few changes such as decreased intensity and shifting of wavenumbers. The peaks in the $2916 \mathrm{~cm}^{-1}$ area were seemed to be sharpened and narrow with pectin addition, indicating the appearance of amorphous region in cellulose structure (Rathinamoorthy et al. 2019). Another peak change appeared in the region of $1065 \mathrm{~cm}^{-1}$ which could be owed to changes in $\mathrm{C}-\mathrm{O}-\mathrm{C}$ and $\mathrm{C}-\mathrm{O}$ vibration stretching. This result suggests that there are interactions between $\mathrm{BC}$ and pectin incorporated in the structure of $\mathrm{BC}$, certainly because of the creation of an interconnected network between two polymers of similar structure and chemical features (Cacicedo et al. 2018).

\section{Mechanical properties}

The addition of pectin to the G. xylinus growth medium resulting in biocomposites with lower mechanical strength than native $\mathrm{BC}$ (Table 1). This finding is in line with that obtained by Szymanska-Chargot et al. (2017) and Gu and Catchmark (2014). The type of polysaccharide added to the G. xylinus growth medium greatly influenced the interaction and structure of the $\mathrm{BC}$ fiber formed. The decreased tensile and tear strength of BCP biocomposites was due to increasing amorphous region in the $\mathrm{BCP}$ structure as proven by decreasing crystallinity as observed by XRD analysis and FTIR spectra. Reduced tensile strength resulted in increased deformability as suggested by Baron et al. (2017), which also means reduced stiffness of biocomposites produced.

The tensile and tear strength of all biocomposites were comparable to those conventional non-biodegradable packaging materials such as high-density polyethylene (HDPE) and low-density polyethylene (LDPE) which have tensile strength values of 17.3-44.8 and 8.2-31.4 MPa, and tear strength values of $0.80-2.40$ and $8-12 \mathrm{~g} / \mu \mathrm{m}$, respectively (Selke et al. 2015).

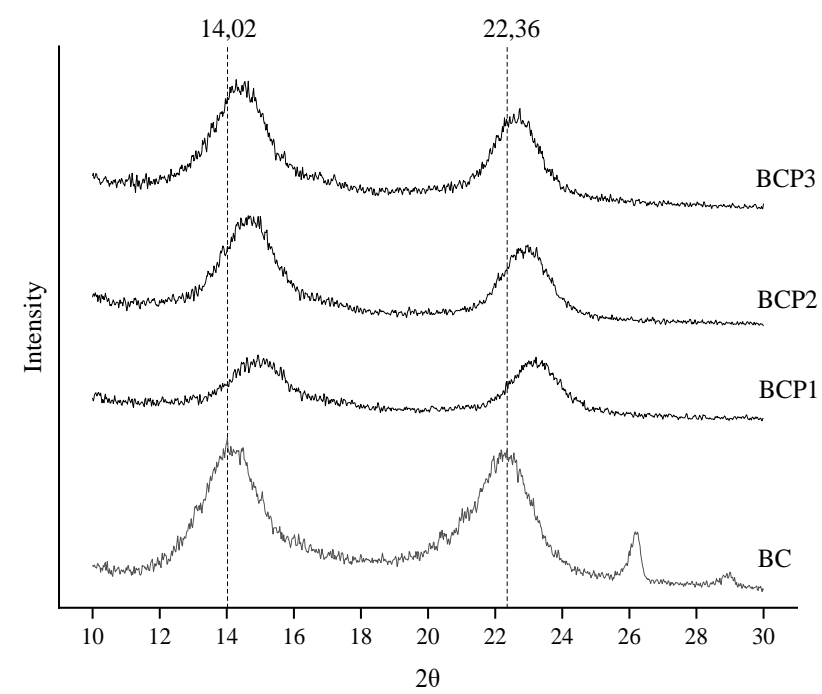

Figure 2. XRD pattern of $\mathrm{BC}$ incorporated with various pectin concentration 
Table 1. Crystallinity and mechanical properties of $\mathrm{BC}$ incorporated with various pectin concentrations

\begin{tabular}{|c|c|c|c|c|c|c|}
\hline \multirow[b]{2}{*}{ Sample } & \multirow{2}{*}{ Crystallinity (\%) } & \multirow{2}{*}{$\begin{array}{c}\text { Crystallite size } \\
(\mathbf{n m})\end{array}$} & \multicolumn{2}{|c|}{ d-spacing } & \multirow{2}{*}{$\begin{array}{c}\text { Tensile strength } \\
(\mathrm{MPa})\end{array}$} & \multirow{2}{*}{$\begin{array}{c}\text { Tear strength } \\
(\mathrm{g} / \mu \mathrm{m})\end{array}$} \\
\hline & & & 110 & 002 & & \\
\hline $\mathrm{BC}$ & 90.63 & 3.06 & 0.3147 & 0.2036 & $108.59 \pm 0.53 b$ & $27.77 \pm 0.50 \mathrm{~b}$ \\
\hline $0.1 \%$ BCP & 77.56 & 3.41 & 0.3047 & 0.1981 & $23.05 \pm 0.55 \mathrm{a}$ & $12.80 \pm 0.99 a$ \\
\hline $0.2 \% \mathrm{BCP}$ & 79.19 & 2.68 & 0.3158 & 0.2047 & $25.72 \pm 0.95 \mathrm{a}$ & $9.63 \pm 0.61 \mathrm{a}$ \\
\hline $0.3 \% \mathrm{BCP}$ & 79.62 & 1.81 & 0.3134 & 0.1975 & $24.16 \pm 0.51 \mathrm{a}$ & $15.72 \pm 0.80 \mathrm{a}$ \\
\hline
\end{tabular}

Table 2. Color properties of BC incorporated with various pectin concentrations

\begin{tabular}{lccccc}
\hline \multicolumn{1}{c}{ Sample } & $\mathbf{L}^{*}$ & $\mathbf{a}^{*}$ & $\mathbf{b}^{*}$ & Color Difference & Opacity \\
\hline BC & $70.45 \pm 0.01 \mathrm{c}$ & $-3.23 \pm 0.01 \mathrm{~d}$ & $-0.98 \pm 0.01 \mathrm{~b}$ & - & $6.32 \pm 0.03 \mathrm{a}$ \\
BCP $0.1 \%$ & $37.40 \pm 0.16 \mathrm{a}$ & $-1.70 \pm 0.03 \mathrm{a}$ & $-2.25 \pm 0.02 \mathrm{a}$ & $43.28 \pm 1.19$ & $6.57 \pm 0.94 \mathrm{a}$ \\
BCP 0.2\% & $37.73 \pm 0.00 \mathrm{~b}$ & $-2.12 \pm 0.01 \mathrm{c}$ & $-1.44 \pm 0.01 \mathrm{~d}$ & $40.71 \pm 1.20$ & $7.02 \pm 0.11 \mathrm{a}$ \\
BCP 0.3\% & $37.71 \pm 0.01 \mathrm{~b}$ & $-1.91 \pm 0.02 \mathrm{~b}$ & $-0.32 \pm 0.02 \mathrm{c}$ & $41.82 \pm 1.21$ & $21.79 \pm 0.57 \mathrm{~b}$ \\
HDPE $^{*}$ & $93.70 \pm 0.10$ & $-0.61 \pm 0.02$ & $3.20 \pm 0.10$ & - & $35.20 \pm 0.20$ \\
\hline
\end{tabular}

Note: *Bonilla et al. (2020)

\section{Crystallinity properties}

Some crucial characteristics to determine the behavior of crystalline material are observed using X-ray diffraction. BC's general XRD spectrum, which is often accompanied by other relatively weak peaks at $\sim 16^{\circ}$, are the two intensive peaks at $2 \theta=\sim 14^{\circ}$ and $\sim 22^{\circ}$ which are generally identified as typical cellulose I profile (Sugiyama et al. 1991).

The diffractogram of bacterial cellulose produced with pectin addition was analogous to that of native $\mathrm{BC}$, but with slightly different peak width and intensity. Figure 2 showed that the XRD pattern of $\mathrm{BC}$ revealed two specific peaks at $2 \theta=14.02^{\circ}$ and $22.36^{\circ}$. The addition of pectin shifts the $2 \theta$ peak and decreases the intensity, while the peak pattern remains the same. This indicates that cellulose crystalline structure was not affected by the pectin supplementation. However, addition of pectin resulted in decreased crystallinity of $\mathrm{BCP}$ compared to native $\mathrm{BC}$. This may be due to intermolecular reaction between pectin and cellulose, which restricted the movement of $\mathrm{BC}$ molecular chains (Cai et al. 2016). Another possible reason is the formation of amorphous $\mathrm{BC}$ or other amorphous polymers (Dayal and Catchmark 2016). The BCP biocomposite also showed changes in crystal size and dspacing (Table 1). The incorporation of pectin reduced the crystal size and improved the d-spacing value, indicating the formation of a wider amorphous area in the resulting biocomposite, thus decreasing crystallinity. Pectin can interfere with the crystallization process during the formation of $\mathrm{BC}$ microfibrils, resulting in a biocomposite with lower crystallinity (Dayal and Catchmark 2016).

\section{BC morphology}

BC biosynthesis is well known for its' singledirectional growth and crystal formation, in which glucose molecules are bound together with $\beta(1 \rightarrow 4)$ glycosidic bond (Tokoh et al. 2002). From Figure $3 \mathrm{a}$ the morphology of $\mathrm{BC}$ native can be seen as being some interwoven cellulose fibrils with many hollow parts. The arrangement of these fibrils forms pores with different diameter sizes (Lin et al. 2018). The presence of pectin impacted the size of the pore formed, in which the pectin appeared to fill the empty space between the fibrils, resulting in a composite with a smaller pore size (Figure 3b). Pectin was also seen to form a layer on the cellulose surface (Figure 3c), or agglomerate around cellulosic fibrils due to the nonuniform dispersion of pectin (Figure 3d). It was validated, as alluded to in the FTIR study, that pectin may render the cellulose fibril intermolecular bond.

\section{Color properties and opacity}

CIELab color values and opacity measurements of biocomposites as affected by pectin addition are presented in Table 2. The native BC film had the highest $\mathrm{L}^{*}$ (lightness) value, which indicated that this film was more white and clear compared to other biocomposites with pectin addition. Presence of pectin in the biocomposites had a direct influence on the color and opacity of the films. This is due to the natural appearance of pectin granule which showed a light brownish color. Incorporation of pectin in the $\mathrm{BC}$ structure resulting in lower $\mathrm{L}^{*}$ value with higher redness $\left(\mathrm{a}^{*}\right)$ and lower yellowness $\left(\mathrm{b}^{*}\right)$. There are no significant differences observed in color difference for all $\mathrm{BCP}$ treatments, suggesting no visual difference between BCP films. As shown in Table 2, the opacity value of biocomposite was increased by adding pectin concentration but with no significant differences, except for $0.3 \%$ BCP. Higher value of opacity indicating lower transparency (Atef et al. 2014). BCP showed a lower opacity compared to conventional HDPE plastic, which indicating the potential application of $\mathrm{BCP}$ as transparent biodegradable food packaging material. 

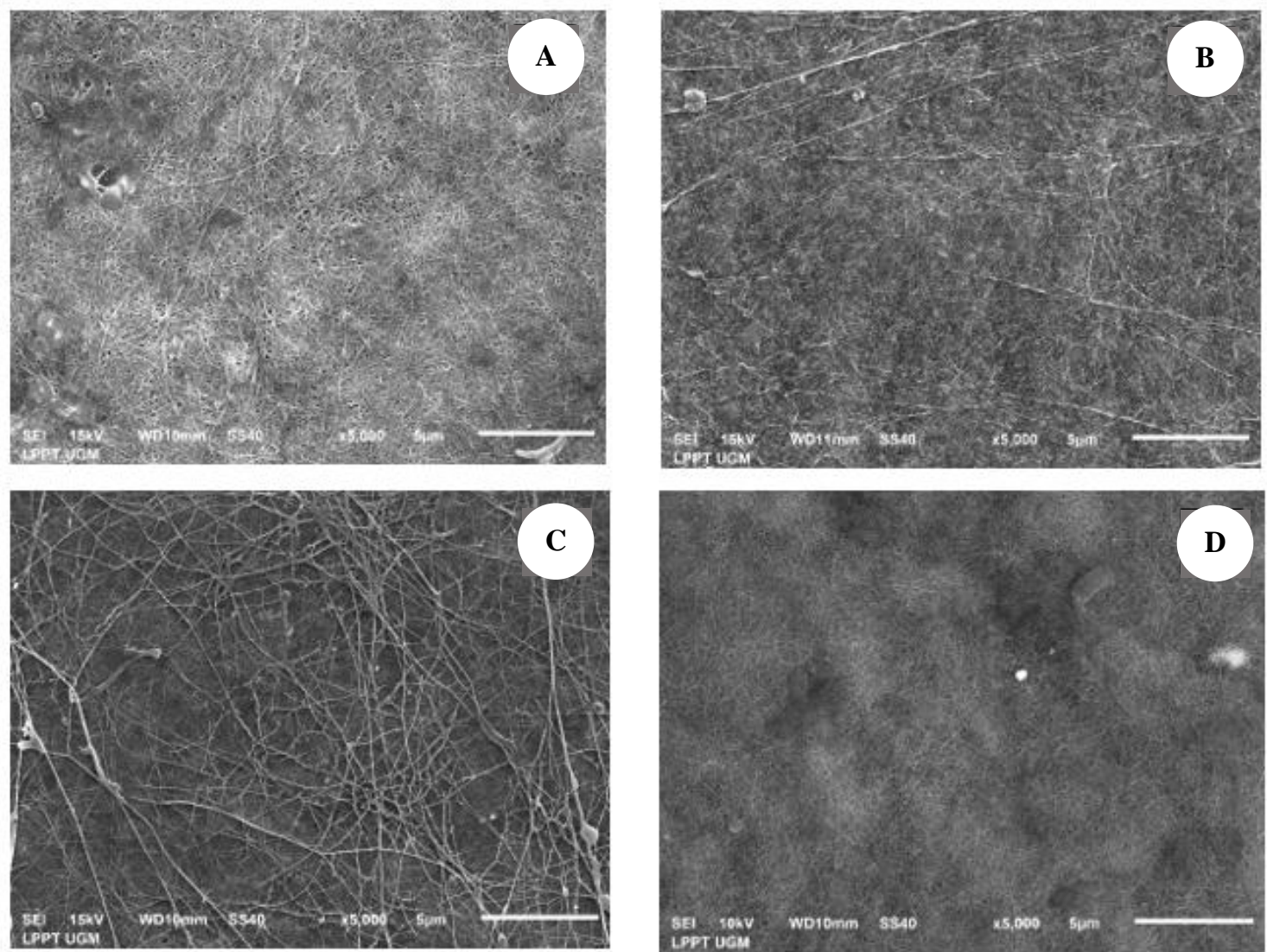

Figure 3. Surface morphology of: A. BC, B. $0.1 \%$ BCP, C. $0.2 \%$ BCP, D. $0.3 \%$ BCP

In conclusion, incorporation of pectin into $\mathrm{BC}$ matrix generally decreased tensile and tear strength, crystallinity properties, lightness and opacity of the biocomposite generated by interlinkage of pectin and $\mathrm{BC}$ polymer through H-bonding. Pectin can spread well in the BC matrix, resulting in better film quality based on tensile strength and opacity values. The biocomposite was slightly transparent with excellent mechanical properties compared to conventional non-biodegradable plastics, suggesting the potential of $\mathrm{BCP}$ as a green packaging alternative for food products.

\section{ACKNOWLEDGEMENTS}

The authors gratefully acknowledge the financial support of the Educational Fund Management Institute (LPDP), Ministry of Finance of the Republic of Indonesia within the framework of the 2016 BUDI DN program.

\section{REFERENCES}

American Society for Testing and Materials. 2002. ASTM D 882-02. Standard Test Method for Tensile Properties of Thin Plastic Sheeting. ASTM International, West Conshohocken, PA, USA.

Atef M, Rezaei M, Behrooz R. 2014. Preparation and characterization agar-based nanocomposite film reinforced by nanocrystalline cellulose. Int J Biol Macromol 70: 537-544. DOI: 10.1016/j.ijbiomac.2014.07.013

Atykyan N, Revin V, Shutova V. 2020. Raman and FT-IR Spectroscopy investigation the cellulose structural differences from bacteria Gluconacetobacter sucrofermentans during the different regimes of cultivation on a molasses media. AMB Exp 10: 84 . DOI: 10.1186/s13568-020-01020-8

Baron RD, Pérez LL, Salcedoa JM, Córdoba LP, Sobral PJdA. 2017. Production and characterization of films based on blends of chitosan from blue crab (Callinectes sapidus) waste and pectin from Orange (Citrus sinensis Osbeck) peel. Intl J Biol Macromol 98: 676-683. DOI: 10.1016/j.ijbiomac.2017.02.004

Barud HS, Regiani T, Marques RFC, Lustri WR, Messaddeq Y, Ribeiro SJL. 2011. Antimicrobial bacterial cellulose-silver nanoparticles composite membranes. J Nanomater 2011: 721631. DOI: $10.1155 / 2011 / 721631$

Bonilla J, Paiano RB, Lourenço RV, Bittante AMQB, Sobral PJA. 2020. Biodegradability in aquatic system of thin materials based on chitosan, PBAT and HDPE polymers: Respirometric and physicalchemical analysis. Intl J Biol Macromol 164: 1399-1412. DOI: 10.1016/j.ijbiomac.2020.07.309

Cacicedo ML, Islan GA, Drachemberg MF, Alvarez V, Bartel L, Bolzan A, Castro GR. 2018. Hybrid bacterial cellulose-pectin films for delivery of bioactive molecules. $\mathrm{N}$ J Chem 42: 7457-7467. DOI: 10.1039/C7NJ03973E.

Cai Z, Chen P, Jin H, Kim J. 2009. The effect of chitosan content on the crystallinity, thermal stability, and mechanical properties of bacterial cellulose-chitosan composites. Proc Inst Mechanical Eng Part C: J Mech Eng Sci 223: 2225-2230. DOI: 10.1117/12.815586.

Chen Y, Zhou X, Lin Q, Jiang D. 2014. Bacterial cellulose/gelatin composites: in situ preparation and glutaraldehyde treatment. Cellulose 21: 2679-2693. DOI: 10.1007/s10570-014-0272-9.

Dayal MS, Catchmark JM. 2016. Mechanical and structural property analysis of bacterial cellulose composites. Carbohydr Polym 144: 447-453. DOI: 10.1016/j.carbpol.2016.02.055. 
Gu J, Catchmark JM. 2014. Roles of xyloglucan and pectin on the mechanical properties of bacterial cellulose composite films Cellulose 21: 275-289. DOI: 10.1007/s10570-013-0115-0.

Hu W, Chen S, Yang J, Li Z, Wang H. 2014. Functionalized bacterial cellulose derivatives and nanocomposites. Carbohydr Polym 101: 1043-1060. DOI: 10.1016/j.carbpol.2013.09.102.

Huang HC, Chen LC, Lin SB, Hsu CP, Chen HH. 2010. In situ modification of bacterial cellulose network structure by adding interfering substances during fermentation. Bioresour Technol 101: 6084-6091. DOI: 10.1016/j.biortech.2010.03.031.

Jia Y, Wang X, Huo M, Zhai X, Li F, Zhong C. 2017. Preparation and characterization of a novel bacterial cellulose/chitosan bio-hydrogel. Nanomater Nanotechnol 7: 1-8. DOI: 10.1177/1847980417707172.

Klemm D, Schumann D, Kramer F, Hebler N, Hornung M, Schmauder HP, Marsch S. 2006. Nanocelluloses as innovative polymers in research and application. In: Klemm D (eds.). Polysaccharides II Advances in polymer science Vol 205. Springer, Berlin. DOI: 10.1007/12_097

Lin D, Lopez-Sanchez P, Gidley MJ. 2016. Interactions of pectins with cellulose during its synthesis in the absence of calcium. Food Hydrocoll 52: 57-68. DOI: 10.1016/j.foodhyd.2015.06.004.

Lin D, Lopez-Sanchez P, Selway N, Gidley MJ. 2018. Viscoelastic properties of pectin/cellulose composites studied by QCM-D and oscillatory shear rheology. Food Hydrocoll 79: 13-19. DOI: 10.1016/j.foodhyd.2017.12.019.

Rathinamoorthy R, Aarthi T, Shree CA, Haridharani P, Shruthi V, Vaishnikka RL. 2019. Development and characterization of selfassembled bacterial cellulose nonwoven film. J Nat Fibers. DOI: 10.1080/15440478.2019.1701609.

Ruka DR, Simon GP, Dean KM. 2013. In situ modifications to bacterial cellulose with the water-insoluble polymer poly-3-hydroxybutyrate. Carbohydr Polym 92 (2): 1717-1723. DOI: 10.1016/j.carbpol.2012.11.007.

Selke SEM, Culter JD, Auras RA. 2015. Major plastics in packaging, Plastics Packaging. Carl Hanser Verlag $\mathrm{GmbH} \& \mathrm{Co} \mathrm{KG}$, Cincinnati. DOI: 10.3139/9783446437197.fm.
Saibuatong O, Phisalapong M. 2010. Novo aloe vera-bacterial cellulose composite film from biosynthesis. Carbohydr Polym 79: 455-460. DOI: 10.1016/j.carbpol.2009.08.039.

Sugiyama J, Persson J, Chanzy H. 1991. Combined infrared and electron diffraction study of the polymorphism of native celluloses. Macromolecules 24: 4168-4175. DOI: 10.1021/ma00009a050.

Sya'di YK, Wahyuni ET, Rahayu ES, Cahyanto MN. 2017a. The effect of polysaccharide in the fermentation medium on physical properties of bacterial cellulose from Gluconacetobacter xylinus BTCC B796. Pak J Biotechnol 14 (3): 323-327.

Sya'di YK, Wahyuni ET, Rahayu ES, Cahyanto MN. 2017b. Effect of culture conditions on the properties of bacterial cellulose produced by Gluconacetobacter xylinus BTCC B796. Intl J Sci Technol 5: 98-103.

Szymanska-Chargot M, Chylinska M, Cybulska J, Koziol A, Pieczywek PM, Zdunek A. 2017. Simultaneous influence of pectin and xyloglucan on structure and mechanical properties of bacterial cellulose composites. Carbohydr Polym 174: 970-979. DOI: 10.1016/j.carbpol.2017.07.004.

Tokoh C, Takabe KJ, Fujita M. 2002. Cellulose synthesized by Acetobacter xylinum in the presence of plant cell wall polysaccharides. Cellulose 9 (1): 65-74. DOI: 10.1023/A:1015827121927.

Ul-Islam M, Shah N, Ha JH, Park JK. 2011. Effect of chitosan penetration on physic-chemical and mechanical properties of bacterial cellulose. Korean J Chem Eng 28: 1736-1743. DOI: 10.1007/s11814-0110042-4.

Wang X, Guo C, Hao W, Ullah N, Chen L, Li Z, Feng X. 2018. Development and characterization of agar-based edible films reinforced with nano-bacterial cellulose. Intl J Biol Macromol 118: 722-730. DOI: 10.1016/j.ijbiomac.2018.06.089.

Yamanaka S, Ishihara M, Sugiyama J. 2000. Structural modification of bacterial cellulose. Cellulose 7: 213-225. DOI: 10.1023/A:1009208022957.

Zhou X, Liu L, Chen Y, Xu S, Chen J. 2007. Efficient biodegradation of cyanide and ferrocyanide by Na-alginate beads immobilized with fungal cells of Trichoderma koningii. Can J Microbiol 53 (9): 10331037. DOI: 10.1139/W07-070. 